\title{
Synthesis of spirolactams via Diels-Alder addition of 1,3-butadienes to an $\alpha$-methylene lactam
}

\author{
Margaret A. Brimble,* Daryl Crimmins, and Michael Trzoss \\ Department of Chemistry, The University of Auckland, Private Bag 92019, \\ Auckland, New Zealand \\ E-mail:m.brimble@auckland.ac.nz \\ (received 24 Sept 04; accepted 19 Oct 04; published on the web 02 Nov 04)
}

\begin{abstract}
As part of a programme directed towards the synthesis of the bicyclic spiroimine ring systems present in the marine toxins, the spirolides and gymnodimine, a study of the Diels-Alder addition of dienes 8, 12, cyclopentadiene and 2,3-dimethyl-1,3-butadiene to $\alpha$-methylene lactam 7 was undertaken. A systematic study of the use of a variety of Lewis acids to catalyze the Diels-Alder reaction was undertaken. Extension of this work to an asymmetric variant of these Diels-Alder reactions was investigated using the chiral Lewis acids $\left[(S, S)-{ }^{t} \mathrm{Bu}-\mathrm{BOX}\right] \mathrm{Cu}(\mathrm{OTf})_{2}$ and $\left[(S, S){ }^{t} \mathrm{Bu}-\right.$ $\mathrm{BOX}] \mathrm{Cu}\left(\mathrm{SbF}_{6}\right)_{2}$.
\end{abstract}

Keywords: $\alpha$-Methylenelactams, Diels-Alder reaction, spirolactams, spirolides, gymnodimine

\section{Introduction}

Gymnodimine $^{1} \mathbf{1}$ is a potent marine biotoxin ${ }^{2}$ isolated from New Zealand oysters (Tiostrea chilensis) that exhibits neurotoxic effects in a mouse bioassay and contains an azaspiro[5.5] undecadiene subunit. This 6,6-spirocyclic ring system is also present in the fast acting toxin spiro-procentrimine ${ }^{3}$ isolated from a Taiwanese laboratory-cultured Procentrum species. Macrocyclic toxins, spirolides A-D 2-5, ${ }^{4,5,6}$ isolated from the digestive glands of contaminated mussels (Mytilus edulis), scallops (Placopecten magellanicus) and toxic plankton from the eastern coast of Canada, contain a homologous 7,6-spirocylic imine ring system. This 7,6-spirocyclic imine ring system is also present in the related shellfish toxins, the pinnatoxins ${ }^{7,8}$ and pteriatoxin. ${ }^{9}$ The spirolides activate L-type calcium channels and act as muscarinic acetylcholine receptor antagonists, however, the related spirolides $\mathrm{E}$ and $\mathrm{F}^{10}$ in which the spiromine unit was hydrolyzed, were found to be inactive. This observation together with the fact that gymnodamine in which the imine moiety is reduced, also resulted in a significant decrease in toxicity, ${ }^{11}$ suggest the importance of this key structural feature on biological activity. 

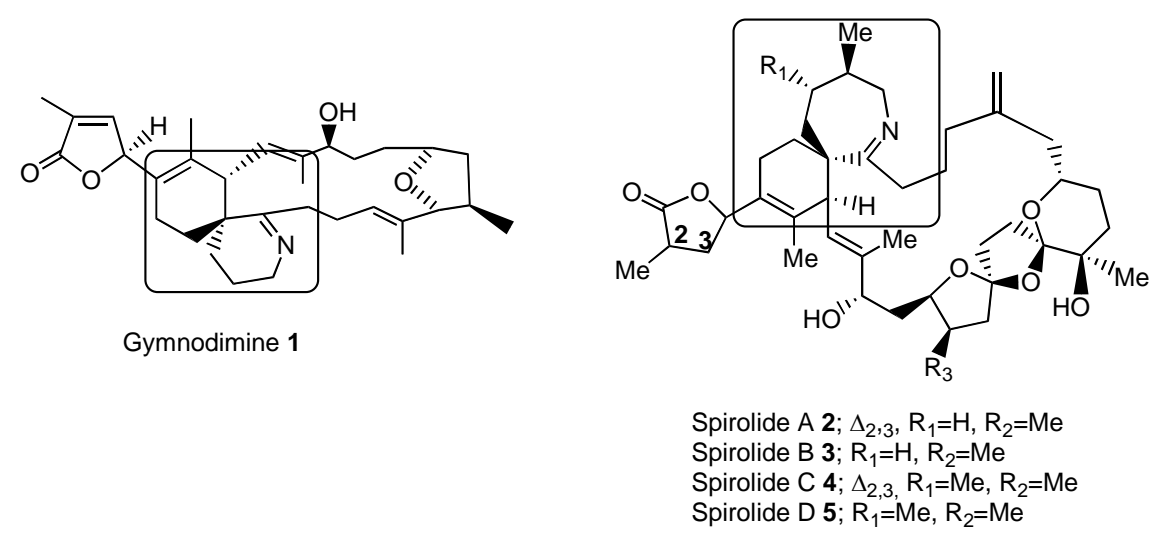

The mechanism of action of these imine-containing toxins was initially thought to involve covalent bond formation via nucleophilic addition to the imine, however Romo et al. ${ }^{12}$ postulate that these $\alpha$-quaternary substituted imines may serve as latent nucleophiles as a result of their masked enamine character as evidenced by their ability to completely incorporate deuterium at the exocyclic carbon after prolonged exposure to $\mathrm{CD}_{3} \mathrm{OD}$.

As part of a programme directed towards the synthesis of the spirolides, ${ }^{13}$ we focused our attention on the synthesis of the unsubstituted spiromine units using a double alkylation - ring closing metathesis approach. ${ }^{14}$ Difficulties adapting this strategy to the synthesis of more substituted systems prompted us to pursue an alternative approach to these heterocyclic frameworks via Diels-Alder addition of an appropriate diene to an $\alpha$-methylene lactam. At the outset of this study the use of $\alpha$-methylene lactams as dienophiles was rare, ${ }^{15}$ however, during the course of this work several communications on the use of $\alpha$-methylenelactams as dienophiles to construct spirolactams appeared in the literature. ${ }^{16}$ We therefore herein report the full details of our preliminary work in this area and offer some improvements to the synthesis of the $\alpha$ methylenelactam and diene starting materials. An aza-Wittig strategy is the only successful method that has been used to date to construct the spiroimine moiety in the total synthesis of the complex pinnatoxins. ${ }^{17,18}$ White et al. ${ }^{19}$ effected an intramolecular condensation of an amine to a silyl enol ether in their approach to the spiromine unit of gymnodimine after experiencing considerable difficulty in using a Diels-Alder strategy to construct the six membered ring.

\section{Results and Discussion}

Treatment of caprolactam with butyl-lithium and benzyl chloroformate afforded CBz-protected caprolactam $\mathbf{6}^{20}$ (Scheme 1) that was converted in one step to the seven membered $\alpha$-methylene lactam 7 by treatment with LHMDS and Eschenmoser's salt followed by in situ methylation and elimination. This one step procedure was adapted from related work by Najera et al. ${ }^{21}$ on the synthesis of five membered $\alpha$-methylene lactams and offers an improvement on the four step conversion of CBz-protected caprolactam 6 to $\alpha$-methylene lactam 7 reported in a communication by Murai et al. ${ }^{16}$, that proceeds via a silyl ketene acetal intermediate. 


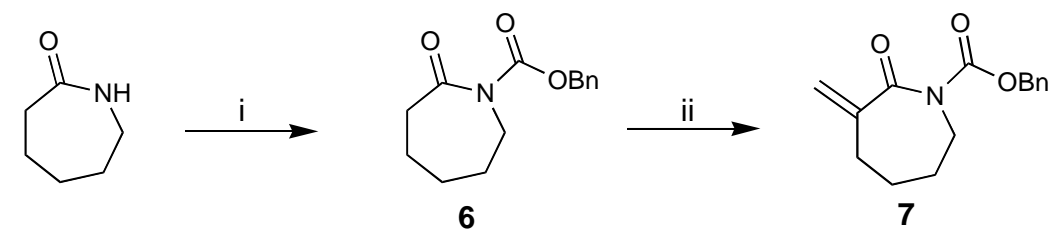

Reagents and Conditions: (i) BuLi, CBzCl, THF, $-78^{\circ} \mathrm{C}, 87 \%$; (ii) $\mathrm{LHMDS}_{2} \mathrm{CH}_{2}=\mathrm{NMe}_{2}^{+} \mathrm{I}^{-}, \mathrm{Mel}, \mathrm{MeOH}$, room temp., $42 \%$.

\section{Scheme 1}

Diene 8 was selected as the initial $4 \pi$ component for the Diels-Alder reaction in that it contains two protected hydroxymethyl groups for further elaboration after construction of the spirolactam ring system. Our initial approach to diene 8 (Scheme 2) involved stannylcupration of 2-butyn-1-ol following the protocol developed by Piers, ${ }^{22}$ affording $(E)$-vinylstannane 9 in $62 \%$ yield. Protection of the alcohol as a $p$-methoxybenzyl ether $\mathbf{1 0}$ followed by tin-lithium exchange and reaction of the resultant vinyl-lithium with the Weinreb amide derived from benzyloxyacetyl chloride afforded $(E)$-enone 11. Subsequent Wittig olefination then provided the desired $(E)$ diene 8. During the course of our work, White et al. ${ }^{19}$ also reported a synthesis of vinyl stannane 10 via stannylcupration of ethyl 2-butynoate and its subsequent lithiation and reaction with a Weinreb amide.

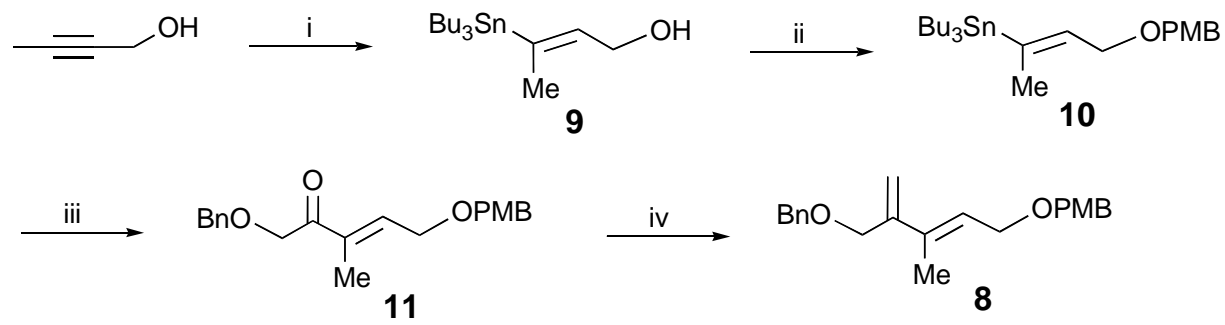

Reagents and Conditions: (i) $\mathrm{Bu}_{3} \mathrm{Sn}(\mathrm{Bu}) \mathrm{CuCNLi}_{2},-78^{\circ} \mathrm{C}, 62 \%$; (ii) $\mathrm{NaH}, \mathrm{PMBCl}, 61 \%$; (iii) $\mathrm{BuLi}, \mathrm{THF}, 78^{\circ} \mathrm{C}$, BnOCH ${ }_{2} \mathrm{CONMeOMe}_{4}$ 42\%; (iv) $\mathrm{Ph}_{3} \mathrm{P}^{+} \mathrm{Me} \mathrm{I}$, BuLi, $0^{\circ} \mathrm{C}, 35 \%$.

\section{Scheme 2}

Difficulties associated with carrying out the stannylcupration on a large scale prompted us to investigate an alternative synthesis of diene 8 (Scheme 3). A better approach involved Wittig reaction of ylide 13 with either aldehyde 14 or 15 to afford enones 11 and 16 respectively, with high $(E)$-selectivity. Notably Wittig reaction using aldehyde $\mathbf{1 5}$ in which the hydroxyl group was protected as a bulky tert-butyldimethylsilylether, preceded with greater $(E)$-selectivity than the analogous reaction using $p$-methoxybenzyl protected aldehyde 14. Ylide $\mathbf{1 3}$ was readily prepared by reaction of ethyltriphenylphosphonium bromide with butyl-lithium followed by addition of benzyloxyacetyl chloride. Reaction of ylide 13 with aldehyde 14 proceeded in high yield in dichloromethane at room temperature whereas aldehyde $\mathbf{1 5}$ required gentle refluxing conditions 
to effect smooth reaction. Finally standard Wittig methylenation of enones $\mathbf{1 1}$ and $\mathbf{1 6}$ afforded dienes 8 and 12 respectively. A further advantage of this latter method is the elimination of the need to deal with toxic tin reagents.

Before investigating the asymmetric Diels-Alder addition of substituted 1,3-butadienes 8 and 12 to $\alpha$-methylene lactams, we initially examined the addition of cyclopentadiene and 2,3dimethyl-1,3-butadiene to $\alpha$-methylene lactam 7 (Table 1). There was good literature precedent for high asymmetric induction using bidentate bis(oxazoline) BOX-copper (II) complexes in catalytic asymmetric Michael and Diels-Alder additions to substrates that can participate in catalyst chelation. $^{23}$ Extension of this idea to the use of benzyloxycarbonyl-protected $\alpha$ methylene lactams seemed a logical step. Given that higher levels of asymmetric induction were observed $^{24}$ in Diels-Alder reactions catalyzed by BOX-copper (II) complexes when the noncoordinating hexafluoroantimonate counterion was used, both BOX-copper (II) triflate and hexafluoroantimonate complexes were evaluated in the present study. In the present work use of the hexafluoroantimonate complex resulted in loss of the tert-butyldimethylsilyl group when using diene 12, thus prompting the parallel synthesis of the $p$-methoxybenzyl protected diene $\mathbf{8}$.

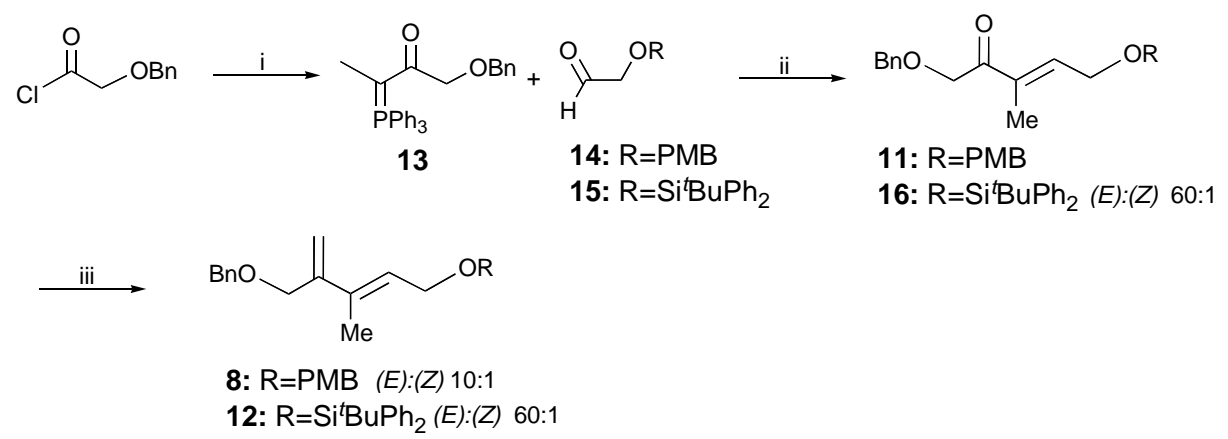

Reagents and Conditions: (i) $\mathrm{Ph}_{3} \mathrm{P}^{+} \mathrm{Et} \mathrm{Br}$, BuLi, THF, $78^{\circ} \mathrm{C}, 53 \%$; (ii) $\mathrm{CH}_{2} \mathrm{Cl}_{2}$, room temp., $24 \mathrm{~h}, 14,91 \%$, reflux, 48h, 15,95\%;

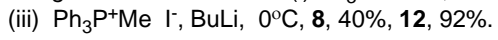

\section{Scheme 3}

The chiral BOX-copper (II) triflate complexes were formed by reacting $[(S),(S)]$-tBu-BOX] ligand with copper (II) triflate in dichloromethane at room temperature for $6 \mathrm{~h}$ giving a characteristically blue solution. The cationic hexafluoroantimonate complexes were prepared by anion exchange from the pre-formed copper (II) chloride complex using silver (I) hexafluoroantimonate, followed by filtration through Celite to remove the precipitated silver (I) chloride.

Addition of cyclopentadiene to $\alpha$-methylenelactam 7 in dichloromethane at room temperature for $3 \mathrm{~h}$ in the presence of $20 \mathrm{~mol} \%\left[(S, S){ }^{t} \mathrm{Bu}-\mathrm{BOX}\right] \mathrm{Cu}(\mathrm{OTf})_{2}$ provided Diels-Alder adduct $17 \mathrm{in}$ $53 \%$ yield as a 2:1 ratio of exo:endo isomers. This result was in agreement with a similar study by Murai et al. ${ }^{16}$ in which the slight exo-selectivity (exo:endo 1.6:1) observed in Diels-Alder reactions using a conformationally rigid cyclic cisoid dienophile is accounted for by Berson's 
dipole moment hypotheses. ${ }^{25,26}$ The enantiomeric excess was determined to be $58 \%$ by chiral HPLC on a Chiralpak ${ }^{\mathrm{TM}}$ ADH column using 99:1 hexane: ${ }^{i} \mathrm{PrOH}$ at a flow rate of $0.3 \mathrm{~mL} /$.

Table 1. Reaction of $\alpha$-methylene lactam 7 with dienes using bis(oxazoline)-copper complexes

Entry Diene Dienophile

\# Absolute configurations of the products have not been established.

The reaction of 2,3-dimethyl-1,3-butadiene with $\alpha$-methylene lactam 7 was next investigated. In this case using $20 \mathrm{~mol} \%\left[(S, S)-{ }^{t} \mathrm{Bu}-\mathrm{BOX}\right] \mathrm{Cu}(\mathrm{OTf})_{2}$ the reaction proceeded sluggishly, with the desired adduct 18 isolated in only $26 \%$ yield after $24 \mathrm{~h}$. The enantiomeric excess was also determined to be $58 \%$ by chiral HPLC using a Chiralpak ${ }^{\mathrm{TM}} \mathrm{ADH}$ column.

Evans et al $^{24}$ report that use of the $\mathrm{SbF}_{6}$ complex accelerates copper (II)-BOX catalysed Diels-Alder reactions. Thus, in order to improve the yield and selectivity of the reaction of 2,3dimethyl-1,3-butadiene with $\alpha$-methylene lactam 7, the $\mathrm{SbF}_{6}$ complex was also investigated (entry 3). Disappointingly the $\mathrm{SbF}_{6}$ complex afforded the adduct $\mathbf{1 8}$ in similar yield but with a significantly improved enantiomeric excess of $94 \%$.

Use of substituted 1,3-butadienes $\mathbf{8}$ and $\mathbf{1 2}$ as the diene component in Diels-Alder reactions with $\alpha$-methylene lactam 7 using both the $\left[(S, S)-{ }^{t} \mathrm{Bu}-\mathrm{BOX}\right] \mathrm{Cu}(\mathrm{OTf})_{2}$ and $\left[(S, S)-{ }^{t} \mathrm{Bu}-\mathrm{BOX}\right]-$ $\mathrm{Cu}\left(\mathrm{SbF}_{6}\right)_{2}$ catalysts proved fruitless in our hands with none of the desired adduct being observed. Expansion of the range of Lewis acid catalysts used to include $\mathrm{Me}_{2} \mathrm{AlCl}, \mathrm{LiClO}_{4}, \mathrm{Sc}(\mathrm{OTf})_{3}$, $\mathrm{Yb}(\mathrm{OTf})_{3}$, albeit in an attempt to prepare racemic Diels-Alder adduct with diene 7, proved equally unrewarding.

In summary the work reported herein focuses on the use of bis(oxazoline)-copper (II) complexes as chiral catalysts for the development of an asymmetric addition of 1,3-butadienes to $\alpha$-methylenelactams. The results obtained indicate that the yields obtained in these reactions are 
moderate thus redirecting our attention to an alternative strategy to construct the spiroimine unit of the spirolides and gymnodimine. Whilst our efforts in this area have proved disappointing, improved syntheses of $\alpha$-methylene lactam 7 and dienes $\mathbf{8}$ and $\mathbf{1 2}$ with full experimental details, are reported herein together with full spectroscopic characterization of the spirolactams $\mathbf{1 7}$ and 18.

\section{Experimental Section}

General Procedures. Melting points were determined using a Kofler hot-stage apparatus and are uncorrected. Optical rotations were determined on a Perkin-Elmer 341 polarimeter. Infrared spectra were recorded with a Perkin-Elmer 1600 series Fourier-transform infrared spectrometer as thin films between sodium chloride plates. ${ }^{1} \mathrm{H}$ and ${ }^{13} \mathrm{C}$ NMR spectra were recorded as indicated on either a Bruker AC200 spectrometer operating at $200 \mathrm{MHz}$ for ${ }^{1} \mathrm{H}$ nuclei and 50 $\mathrm{MHz}$ for ${ }^{13} \mathrm{C}$ nuclei, a Bruker DRX300 spectrometer operating at $300 \mathrm{MHz}$ for ${ }^{1} \mathrm{H}$ nuclei and 75 $\mathrm{MHz}$ for ${ }^{13} \mathrm{C}$ nuclei, or a Bruker DRX400 spectrometer operating at $400 \mathrm{MHz}$ for ${ }^{1} \mathrm{H}$ nuclei and $100 \mathrm{MHz}$ for ${ }^{13} \mathrm{C}$ nuclei. Both ${ }^{1} \mathrm{H}$ and ${ }^{13} \mathrm{C}$ NMR spectra were interpreted with the aid of COSY, HETCOR and DEPT 135 experiments and are reported in ppm downfield from tetramethylsilane as reference. High-resolution mass spectra were recorded using a VG 7070 spectrometer operating with an ionisation potential of $70 \mathrm{eV}$ at a nominal resolution of 5000 or 10000 as appropriate. Major fragments are assigned where possible and their intensities given as percentages of the base peak. Tetrahydrofuran was dried using sodium/benzophenone and distilled prior to use. Flash chromatography was performed using either Merck Kieselgel 60 or Riedel-de-Haën Kieselgel S silica gel (both 230-400 mesh), or Merck aluminium oxide (70-230 mesh), with the indicated solvents. Compounds were visualized under ultraviolet light or by staining with iodine vapour or with vanillin in methanolic sulfuric acid.

Benzyl 2-oxo-1-azepanecarboxylate (6). ${ }^{16,20}$ To a solution of $\varepsilon$-caprolactam $(3.63 \mathrm{~g}$, $32.0 \mathrm{mmol})$ in THF $(70 \mathrm{~mL})$ at $-78{ }^{\circ} \mathrm{C}$ was added $n$-BuLi $(1.6 \mathrm{M}, 32 \mathrm{mmol})$. The reaction mixture was stirred at $\quad-78{ }^{\circ} \mathrm{C}$ for $30 \mathrm{~min}$. Benzyl chloroformate $(41.0 \mathrm{mmol}, 5.85 \mathrm{~mL})$ was then added and the resulting mixture stirred at $-78{ }^{\circ} \mathrm{C}$ for $1 \mathrm{~h}$. The resulting mixture was warmed to room temperature, quenched with water $(20 \mathrm{~mL})$ and extracted with ethyl acetate $(2 \times 20 \mathrm{~mL})$. The combined organic extracts were dried $\left(\mathrm{MgSO}_{4}\right)$ and concentrated in vacuo to give a yellow oil. The residue was purified by flash chromatography (hexane/ethyl acetate 2:1) to give the title compound $6(3.34 \mathrm{~g}, 87 \%)$ as a pale yellow oil. $\delta_{\mathrm{H}}\left(300 \mathrm{MHz} ; \mathrm{CDCl}_{3}\right) 1.74-1.78(6 \mathrm{H}, \mathrm{m}, 4-$, 5-, 6- $\left.\mathrm{CH}_{2}\right), 2.66-2.69\left(2 \mathrm{H}, \mathrm{m}, 3-\mathrm{CH}_{2}\right), 3.83-3.86\left(2 \mathrm{H}, \mathrm{m}, 7-\mathrm{CH}_{2}\right), 5.28\left(2 \mathrm{H}, \mathrm{s}, 1\right.$ '- $\left.\mathrm{CH}_{2}\right), 7.26-7.44$ $\left(5 \mathrm{H}, \mathrm{m}, 2 "-\right.$ to 6"-CH); $\delta_{\mathrm{C}}\left(100 \mathrm{MHz} ; \mathrm{CDCl}_{3}\right) 23.5\left(\mathrm{CH}_{2}, \mathrm{C}-4\right), 28.6\left(\mathrm{CH}_{2}, \mathrm{C}-6\right), 29.1\left(\mathrm{CH}_{2}, \mathrm{C}-5\right)$, $39.4\left(\mathrm{CH}_{2}, \mathrm{C}-3\right), 46.4\left(\mathrm{CH}_{2}, \mathrm{C}-2\right), 68.5\left(\mathrm{CH}_{2}, \mathrm{C}-1^{\prime}\right), 127.9(\mathrm{CH}, \mathrm{C}-2 "$ and $\mathrm{C}-6 "), 128.2(\mathrm{CH}, \mathrm{C}-$ 4"), 128.5 (CH, C-3" and C-5"), 135.5 (quat, $\mathrm{C}-1$ "), 154.3 (quat, $\mathrm{C}=\mathrm{O}, \mathrm{Cbz}$ ), 175.5 (quat, $\mathrm{C}-2$ ). 
Benzyl 3-methylene-2-oxo-1-azepanecarboxylate (7). ${ }^{16}$ To a solution of benzyl-2-oxo-1azepane-carboxylate $(300 \mathrm{mg}, 1.21 \mathrm{mmol})$ in THF $(3 \mathrm{~mL})$ at $-78{ }^{\circ} \mathrm{C}$ was added a freshly prepared solution of LiHMDS $(1.57 \mathrm{mmol})$. The mixture was stirred for $1 \mathrm{~h}$ and then transferred via cannula to a pre-cooled $\left(-78^{\circ} \mathrm{C}\right)$ suspension of Eschenmoser's salt $(492 \mathrm{mg}, 2.66 \mathrm{mmol})$ in THF $(2 \mathrm{~mL})$. The resulting mixture was stirred at $-78{ }^{\circ} \mathrm{C}$ for $4 \mathrm{~h}$ and the temperature was then allowed to rise to room temperature. The resulting solution was quenched with sat. aqueous $\mathrm{NaHCO}_{3}(10 \mathrm{~mL})$ and extracted with ethyl acetate $(3 \times 20 \mathrm{~mL})$. The combined organic layers were washed with brine $(20 \mathrm{~mL})$, dried with anhydrous $\mathrm{MgSO}_{4}$ and the solvents removed in vacuo. The residue was dissolved in dry $\mathrm{MeOH}(10 \mathrm{~mL})$ and an excess of $\mathrm{MeI}(5 \mathrm{~mL})$ was added. The reaction was stirred at RT for $24 \mathrm{~h}$ and the solvent removed in vacuo. Sat. aqueous $\mathrm{NaHCO}_{3}(40 \mathrm{~mL})$ was added and the mixture extracted with ethyl acetate $(2 \times 20 \mathrm{~mL})$. The organic layer was washed with brine $(20 \mathrm{~mL})$, dried $\left(\mathrm{MgSO}_{4}\right)$, and the solvents removed in vacuo. The residue was purified by flash chromatography (hexane/ethyl acetate $4: 1$ ) to give the title compound $7(136 \mathrm{mg}, 42 \%)$ as a yellow oil. $v_{\max }(\mathrm{NaCl}) / \mathrm{cm}^{-1}$ (neat) 3090-3033, 2936, 2859, $1765,1710,1453,1379,1339,1263,1013 ; \delta_{\mathrm{H}}\left(300 \mathrm{MHz}, \mathrm{CDCl}_{3}\right) 1.71-1.80\left(4 \mathrm{H}, \mathrm{m}, 5-, 6-\mathrm{CH}_{2}\right)$, 2.40-2.44 (2H, m, 4-CH $\left.\mathrm{CH}_{2}\right), 3.73-3.76\left(2 \mathrm{H}, \mathrm{m}, 7-\mathrm{CH}_{2}\right), 5.29\left(2 \mathrm{H}, \mathrm{s}, 1\right.$ '- $\left.\mathrm{CH}_{2}\right), 5.43(1 \mathrm{H}, \mathrm{d}, J 1.2$, $3 \mathrm{~A}-H), 5.81(1 \mathrm{H}, \mathrm{d}, J 1.2,3 \mathrm{~B}-H), 7.30-7.45\left(5 \mathrm{H}, \mathrm{m}, 2\right.$ "- to 6"-CH); $\delta_{\mathrm{C}}\left(75 \mathrm{MHz}, \mathrm{CDCl}_{3}\right) 27.9$ $\left(\mathrm{CH}_{2}, \mathrm{C}-5\right), 29.0\left(\mathrm{CH}_{2}, \mathrm{C}-6\right), 32.4\left(\mathrm{CH}_{2}, \mathrm{C}-4\right), 46.3\left(\mathrm{CH}_{2}, \mathrm{C}-7\right), 68.3\left(\mathrm{CH}_{2}, \mathrm{C}-\mathrm{1}^{\prime}\right), 123.8\left(\mathrm{CH}_{2}, 3-\right.$ $\mathrm{CH}_{2}$ ), 127.7 ( $\mathrm{CH}, \mathrm{C}-2 "$ and C-6"), $128.1(\mathrm{CH}, \mathrm{C}-4 "), 128.5(\mathrm{CH}, \mathrm{C}-3 "$ and C-5"), 135.6 (quat, C1'), 146.7 (quat, $\mathrm{C}-3$ ), 154.0 (quat, $\mathrm{C}=\mathrm{O}, \mathrm{Cbz}$ ), 172.1 (quat, $\mathrm{C}-2$ ); $m / z$ (EI): 259 (M+2.5\%), 231 $\left(\mathrm{M}-\mathrm{C}_{2} \mathrm{H}_{4}, 28\right), 107\left(\mathrm{M}-\mathrm{C}_{9} \mathrm{H}_{10} \mathrm{O}_{2}, 152\right)$ and 91 (100); HRMS (EI): Found $\mathrm{M}^{+}, 259.12063$. $\mathrm{C}_{15} \mathrm{H}_{17} \mathrm{NO}_{3}$ requires $M, 259.12084$.

(E)-3-(Tributylstannyl)-2-buten-1-ol (9). To a suspension of $\mathrm{CuCN}$ (18.7 mmol) in THF $(25 \mathrm{~mL})$ was added dropwise $n$-BuLi $(2.16 \mathrm{M}$ in hexane, $18.2 \mathrm{~mL}, 39.3 \mathrm{mmol})$ at $-78{ }^{\circ} \mathrm{C}$. The solution was stirred for $10 \mathrm{~min}$ at $0^{\circ} \mathrm{C}$ (pale yellow colour) then recooled to $-78{ }^{\circ} \mathrm{C}$. Tributyltin hydride $(29.17 \mathrm{mmol}, 7.85 \mathrm{ml})$ was added and the solution was stirred for $10 \mathrm{~min}$ (yellow gold colour) at $-78{ }^{\circ} \mathrm{C}$. A solution of 2-butyn-1-ol $(0.534 \mathrm{~mL}, 7.13 \mathrm{mmol})$ in THF $(5 \mathrm{~mL})$ containing dry $\mathrm{MeOH}(0.491 \mathrm{~mL}, 12.12 \mathrm{mmol})$ was added dropwise to the cuprate reagent at $-100{ }^{\circ} \mathrm{C}$ forming a red solution. The mixture was stirred for $15 \mathrm{~min}$ then allowed to warm to $-78{ }^{\circ} \mathrm{C}$ and stirred for $3 \mathrm{~h}$. Sat. aqueous $\mathrm{NH}_{4} \mathrm{Cl}(30 \mathrm{~mL})$ was added at $-78{ }^{\circ} \mathrm{C}$, the mixture stirred vigorously and allowed to warm to room temperature until the aqueous phase developed a deep blue colour. After extraction with diethyl ether $(2 \times 20 \mathrm{~mL})$, the combined organic layers were washed with brine, dried $\left(\mathrm{MgSO}_{4}\right)$ and concentrated in vacuo. Purification of the residue by flash chromatography (hexane/ether 5:1) provided the title compound 9 as a pale yellow oil (1.58 $\mathrm{g}$, $62 \%$ ). Spectroscopic data were in agreement with those reported in literature. ${ }^{27}$

4"'-Methoxybenzyl (E)-3-(tributylstannyl)-2-butenyl ether (10). To a suspension of sodium hydride $(60 \%$ in mineral oil, $88 \mathrm{mg}, 3.66 \mathrm{mmol})$ in DMF $(10 \mathrm{~mL})$ was added $(E)$-3-(tributylstannyl)-2-buten-1-ol (1.1 g, $3.05 \mathrm{mmol})$ at $0{ }^{\circ} \mathrm{C}$, and the reaction mixture stirred for $30 \mathrm{~min}$. To this mixture was added $p$-methoxybenzyl chloride $(0.5 \mathrm{~mL}, 3.66 \mathrm{mmol})$ and tetrabutylammonium iodide $(255 \mathrm{mg}, 0.7 \mathrm{mmol})$ and the resultant mixture stirred for $18 \mathrm{~h}$ at room 
temperature. The mixture was diluted with sat. aqueous $\mathrm{NH}_{4} \mathrm{Cl}(30 \mathrm{~mL})$ and extracted with diethyl ether $(2 \times 20 \mathrm{~mL})$. The organic phase was washed with sat. aqueous $\mathrm{NH}_{4} \mathrm{Cl}(30 \mathrm{~mL})$, distilled water $(2 \times 20 \mathrm{~mL})$, brine $(20 \mathrm{~mL})$ and dried $\left(\mathrm{MgSO}_{4}\right)$. After removal of the solvent under reduced pressure, the residue was purified by column chromatography (hexane/ether 5:1) to furnish the title compound $\mathbf{1 0}(930 \mathrm{mg}, 61 \%)$ as a colourless oil. Spectroscopic data were in agreement with those reported in literature. ${ }^{19}$

(E)-1-(Benzyloxy)-5-[(4"'-methoxybenzyl)oxy]-3-methyl-3-penten-2-one (11). $n$-BuLi (1.36 M in hexane, $0.26 \mathrm{~mL}, 0.35 \mathrm{mmol}$ ) was added slowly at $-78^{\circ} \mathrm{C}$ to a stirred solution of $4 "$-methoxybenzyl (E)-3-(tributylstannyl)-2-butenyl ether $(0.57 \mathrm{~g}, 1.18 \mathrm{mmol})$ in THF $(3 \mathrm{~mL})$. The mixture was stirred at $-78^{\circ} \mathrm{C}$ for $20 \mathrm{~min}$ then $N$-methoxy- $N$-methyl-2-(benzyloxy)acetamide $(86.6 \mathrm{mg}$, $0.414 \mathrm{mmol})$ in THF $(2 \mathrm{~mL})$ was added dropwise over $5 \mathrm{~min}$. The solution was stirred at $-78^{\circ} \mathrm{C}$ for $15 \mathrm{~min}$ then allowed to warm to $25^{\circ} \mathrm{C}$. After stirring for $1 \mathrm{~h}$, sat. aqueous $\mathrm{NH}_{4} \mathrm{Cl}(20 \mathrm{~mL})$ was added. The mixture was extracted with diethyl ether $(2 \times 20 \mathrm{~mL})$ and the solution subsequently washed with $1 \mathrm{M} \mathrm{KF}(20 \mathrm{~mL})$. The combined organic layers were dried $\left(\mathrm{MgSO}_{4}\right)$, and the solvent evaporated in vacuo. The residue was purified by column chromatography (hexane/ether 2:1) to provide the title compound $11(18 \mathrm{mg}, 42 \%)$ as a pale yellow oil. $v_{\max }$ $(\mathrm{NaCl}) / \mathrm{cm}^{-1}\left(\mathrm{CH}_{2} \mathrm{Cl}_{2}\right) 2985,2928,2859,2305,1687,1612,1550,1513,1421 ; \delta_{\mathrm{H}}(300 \mathrm{MHz}$; $\left.\mathrm{CDCl}_{3}\right) 1.75\left(3 \mathrm{H}, \mathrm{m}, 3-\mathrm{CH}_{3}\right), 3.80\left(3 \mathrm{H}, \mathrm{s}, \mathrm{OCH}_{3}\right), 4.19\left(2 \mathrm{H}, \mathrm{dd}, J_{5,4} 5.5\right.$ and $\left.J_{5,3 \mathrm{Me}} 0.8,5-\mathrm{CH}_{2}\right)$, $4.46\left(2 \mathrm{H}, \mathrm{s}, 1-\mathrm{CH}_{2}\right), 4.47\left(2 \mathrm{H}, \mathrm{s}, 1^{\prime}-\mathrm{CH}_{2}\right), 4.60\left(2 \mathrm{H}, \mathrm{s}, 11^{\prime \prime}-\mathrm{CH}_{2}\right), 6.58-6.62(1 \mathrm{H}, \mathrm{m}, 4-H), 6.88$ $(2 \mathrm{H}, \mathrm{d}, J$ 8.6, 3"- and 5"-CH), $7.25(2 \mathrm{H}, \mathrm{d}, J 8.6,2$ "- and 6"-CH), 7.34-7.36 (5H, m, 2"'-- to 6"'-$\mathrm{CH}) ; \delta_{\mathrm{C}}\left(75 \mathrm{MHz} ; \mathrm{CDCl}_{3}\right) 11.6\left(\mathrm{CH}_{3}, 3-\mathrm{CH}_{3}\right), 55.3\left(\mathrm{CH}_{3}, \mathrm{OCH}_{3}\right), 66.8\left(\mathrm{CH}_{2}, \mathrm{C}-5\right), 71.6\left(\mathrm{CH}_{2}, \mathrm{C}-\right.$ $\left.1^{\prime}\right), 72.8\left(\mathrm{CH}_{2}, \mathrm{C}-1\right), 73.3\left(\mathrm{CH}_{2}, \mathrm{C}-1^{\prime \prime \prime}\right), 113.9$ ( $\mathrm{CH}, \mathrm{C}-3 "$ and $\left.\mathrm{C}-5 "\right), 127.9\left(\mathrm{CH}, \mathrm{C}-4{ }^{\prime \prime \prime}\right), 128.0$ (CH, C-2'"' and C-6"'"), 128.5 (CH, C-3"'" and C-5"'"), 129.5 (CH, C-2" and C-6" ), 129.6 (quat, C1"), 135.7 (quat, C-4'"'), 137.4 (quat, C-3), 138.9 (CH, C-4), 159.4 (quat, C-4"), 196.9 (quat, C2); $m / z$ (DEI): $340\left(\mathrm{M}^{+}, 0.08 \%\right.$ ) and 121 (100); HRMS (EI): Found $\mathrm{M}^{+}, 340.16776 . \mathrm{C}_{21} \mathrm{H}_{24} \mathrm{O}_{4}$, requires $\mathrm{M}^{+}, 340.16746$.

Benzyl (E)-5-[(4"'-methoxybenzyl)oxy]-3-methyl-2-methylene-3-pentenyl ether (8). (E)-1(Ben-zyloxy)-5-[(4"-methoxybenzyl)oxy]-3-methyl-3-penten-2-one 11 (30 mg, $88 \mu \mathrm{mol}$ ) was dissolved in dry THF $(10 \mathrm{~mL})$ at room temperature and then cooled to $0^{\circ} \mathrm{C}$. To this mixture was added methylenetriphenylphosphorane ylide ${ }^{28}$ in THF $(2.2 \mathrm{~mL})$. The reaction mixture was stirred at $0^{\circ} \mathrm{C}$ for $1 \mathrm{~h}$, quenched by the addition of sat. aqueous $\mathrm{NaHCO}_{3}(20 \mathrm{~mL})$ solution and extracted with ether $(3 \times 20 \mathrm{~mL})$. The combined extracts were dried $\left(\mathrm{MgSO}_{4}\right)$ and concentrated. The residue was purified by flash chromatography (hexane/ethyl acetate 9:1) to give the title compound $8(10 \mathrm{mg}, 35 \%)$ as a pale yellow oil; $v_{\max }(\mathrm{NaCl}) / \mathrm{cm}^{-1}$ (neat) $2929,2855,1612,1513$, $1248,1095,1072,1035 ; \delta_{\mathrm{H}}\left(400 \mathrm{MHz} ; \mathrm{CDCl}_{3}\right) 1.81\left(3 \mathrm{H}, \mathrm{m}, 3-\mathrm{CH}_{3}\right), 3.80\left(3 \mathrm{H}, \mathrm{s}, \mathrm{OCH}_{3}\right), 4.12$ $\left(2 \mathrm{H}, \mathrm{d}, J_{5,4} 6.3,5-\mathrm{CH}_{2}\right), 4.22\left(2 \mathrm{H}, \mathrm{s}, 1-\mathrm{CH}_{2}\right), 4.45\left(2 \mathrm{H}, \mathrm{s}, 1^{\prime}-\mathrm{CH}_{2}\right), 4.52\left(2 \mathrm{H}, \mathrm{s}, 1\right.$ ''- $\left.\mathrm{CH}_{2}\right), 5.25$ $\left(1 \mathrm{H}, \mathrm{bs}, 2-\mathrm{CH}_{a} \mathrm{H}_{\mathrm{b}}\right), 5.26\left(1 \mathrm{H}, \mathrm{bs}, 2-\mathrm{CH}_{\mathrm{a}} H_{b}\right), 5.82\left(1 \mathrm{H}, \mathrm{t}, J_{4,5} 6.3,4-H\right), 6.87(2 \mathrm{H}, \mathrm{d}, J 8.6,3$ "- and 5"-CH), $7.26\left(2 \mathrm{H}, \mathrm{d}, J\right.$ 8.6, 2"- and 6"-CH), 7.28-7.35 (5H, m, 2"''- to 6"''-CH); $\delta_{\mathrm{C}}(100 \mathrm{MHz}$; $\left.\mathrm{CDCl}_{3}\right) 14.5\left(\mathrm{CH}_{3}, 3-\mathrm{CH}_{3}\right), 55.3\left(\mathrm{CH}_{3}, \mathrm{OCH}_{3}\right), 66.8\left(\mathrm{CH}_{2}, \mathrm{C}-5\right), 71.3\left(\mathrm{CH}_{2}, \mathrm{C}-1^{\prime}\right), 72.0\left(\mathrm{CH}_{2}, \mathrm{C}-\right.$ 1), $72.2\left(\mathrm{CH}_{2}, \mathrm{C}-1^{\prime \prime \prime}\right), 113.80(\mathrm{CH}, \mathrm{C}-3 "$ and $\mathrm{C}-5 "), 113.9\left(\mathrm{CH}_{2}, 2-\mathrm{CH}_{2}\right), 124.5(\mathrm{CH}, \mathrm{C}-4), 127.6$ 
(CH, C-4'"'), 127.8 (CH, C-2"'" and C-6"'"), 128.4 (CH, C-3"'" and C-5"''), 129.5 (CH, C-2" and C6" ), 130.4 (quat, C-1"), 135.5 (quat, C-4'"'), 138.4 (quat, C-3), 144.9 (quat, C-2), 159.2 (quat, C4"); $m / z$ (EI): $338\left(\mathrm{M}^{+}, 0.3 \%\right), 247\left(\mathrm{M}-\mathrm{C}_{7} \mathrm{H}_{7}, 91\right)$ and 121 (100); HRMS (EI): Found $\mathrm{M}^{+}$, $338.18850 \mathrm{C}_{22} \mathrm{H}_{26} \mathrm{O}_{3}$, requires $\mathrm{M}^{+}, 338.18819$.

1-(Benzyloxy)-3-(triphenyl- $\lambda^{\mathbf{5}}$-phosphanylidene)-2-butanone (13). A solution of $n$-BuLi (1.6 $\mathrm{M}$ in hexane, $10.6 \mathrm{~mL}, 16.96 \mathrm{mmol})$ was added slowly to a stirred suspension of ethyltriphenylphosphonium bromide $(6.3 \mathrm{~g}, 16.96 \mathrm{mmol})$ in $\mathrm{THF}(45 \mathrm{~mL})$ at $-78{ }^{\circ} \mathrm{C}$ producing an orange solution. The mixture was warmed to $0^{\circ} \mathrm{C}$ and stirred for $30 \mathrm{~min}$. The ylide solution was then added dropwise via cannula to a solution of benzyloxyacetyl chloride $(0.84 \mathrm{~mL}, 5.41 \mathrm{mmol})$ in THF $(15 \mathrm{~mL})$, which had been cooled to $-78^{\circ} \mathrm{C}$. The reaction was maintained at $-78{ }^{\circ} \mathrm{C}$ for $1 \mathrm{~h}$, allowed to warm to room temperature for $2 \mathrm{~h}$ then quenched by the addition of sat. aqueous $\mathrm{NH}_{4} \mathrm{Cl}(60 \mathrm{~mL})$. The product was extracted with ethyl acetate $(3 \times 50 \mathrm{~mL})$ and the organic phase washed with sat. aqueous $\mathrm{NaHCO}_{3}(2 \times 50 \mathrm{~mL})$, brine $(2 \times 50 \mathrm{~mL})$ and dried $\left(\mathrm{Na}_{2} \mathrm{SO}_{4}\right)$. Concentration in vacuo gave a red oil, which was recrystallised from hexane/ethyl acetate $(10: 1)$ to give the title compound $\mathbf{1 3}(1.26 \mathrm{~g}, 53 \%)$ as a pale red amorphous solid. $\mathrm{Mp} 98-100^{\circ} \mathrm{C}, v_{\max }$ $(\mathrm{NaCl}) / \mathrm{cm}^{-1}\left(\mathrm{CH}_{2} \mathrm{Cl}_{2}\right)$ 3062, 3030, 2924, 2249, 2225, 1520, 1483; $\delta_{\mathrm{H}}\left(300 \mathrm{MHz}, \mathrm{CDCl}_{3}\right) 1.64$ $\left(3 \mathrm{H}, \mathrm{d}, J_{4, \mathrm{P}} 16.1, \mathrm{CH}_{3}\right), 4.28\left(2 \mathrm{H}, \mathrm{s}, 1-\mathrm{CH}_{2}\right), 4.67\left(2 \mathrm{H}, \mathrm{s}, 1^{\prime}-\mathrm{CH}_{2}\right), 7.26-7.62(20 \mathrm{H}, \mathrm{m}, \mathrm{ArH}) ; \mathrm{m} / z$ (FAB): $439\left(\mathrm{MH}^{+}, 100 \%\right)$; HRMS (FAB): Found $\mathrm{MH}^{+}$, 439.18304. $\mathrm{C}_{29} \mathrm{H}_{28} \mathrm{O}_{2} \mathrm{P}$, requires $\mathrm{MH}^{+}$, 439.18269.

2-[(4"-Methoxybenzyl)oxy]acetaldehyde (14). To a stirred solution of oxalyl chloride $(2.8 \mathrm{~mL}$, $31.9 \mathrm{mmol})$ in $\mathrm{CH}_{2} \mathrm{Cl}_{2}(60 \mathrm{~mL})$ at $-78{ }^{\circ} \mathrm{C}$ was added dimethyl sulfoxide $(2.8 \mathrm{~mL}, 39.1 \mathrm{mmol})$. After $15 \mathrm{~min}$, a solution of ( $p$-methoxybenzyloxy)ethanol $(3 \mathrm{~g}, 16.6 \mathrm{mmol})$ in $\mathrm{CH}_{2} \mathrm{Cl}_{2}(20 \mathrm{~mL})$ was added dropwise. The mixture was maintained at $-78{ }^{\circ} \mathrm{C}$ for $20 \mathrm{~min}$, then $\mathrm{Et}_{3} \mathrm{~N}(9.2 \mathrm{~mL}$, $66.3 \mathrm{mmol}$ ) was added. After stirring for $5 \mathrm{~min}$, the mixture was allowed to warm to room temperature over $1.5 \mathrm{~h}$. Water $(40 \mathrm{~mL})$ was added and the resulting mixture washed with $1 \mathrm{M}$ $\mathrm{HCl}(2 \times 50 \mathrm{~mL})$, sat. aqueous $\mathrm{NaHCO}_{3}(20 \mathrm{~mL})$ and brine $(20 \mathrm{~mL})$. The combined organic extracts were dried $\left(\mathrm{MgSO}_{4}\right)$ and concentrated under reduced pressure to afford the desired crude aldehyde. Purification by flash chromatography (hexane/ethyl acetate 5:1) yielded the title compound $14(1.5 \mathrm{~g}, 50 \%)$ as a yellow oil. Spectroscopic data were in agreement with those reported in literature. ${ }^{29}$

tert-Butyldiphenylsilyloxyacetaldehyde (15). To a stirred solution of oxalyl chloride $(0.48 \mathrm{~mL}$, $5.6 \mathrm{mmol})$ in $\mathrm{CH}_{2} \mathrm{Cl}_{2}(20 \mathrm{~mL})$ at $-78{ }^{\circ} \mathrm{C}$ was added dimethyl sulfoxide $(0.48 \mathrm{~mL}, 6.8 \mathrm{mmol})$. After $15 \mathrm{~min}$, a solution of 2-(tert-butyldiphenylsiloxy)ethanol $(0.7 \mathrm{~g}, 2.88 \mathrm{mmol})$ in $\mathrm{CH}_{2} \mathrm{Cl}_{2}$ $(10 \mathrm{~mL})$ was then added dropwise. The mixture was maintained at $-78{ }^{\circ} \mathrm{C}$ for 20 min then $\mathrm{Et}_{3} \mathrm{~N}$ $(1.6 \mathrm{~mL}, 11.52 \mathrm{mmol}$ ) was added. After stirring for $5 \mathrm{~min}$, the mixture was allowed to warm to room temperature over $1.5 \mathrm{~h}$. Water $(40 \mathrm{~mL})$ was added and the resulting mixture washed with 1 $\mathrm{M} \mathrm{HCl}(2 \times 50 \mathrm{~mL})$, sat. aqueous $\mathrm{NaHCO}_{3}(20 \mathrm{~mL})$ and brine $(20 \mathrm{~mL})$. The combined organic extracts were dried $\left(\mathrm{MgSO}_{4}\right)$ and concentrated under reduced pressure to afford the crude aldehyde. Purification by flash chromatography (hexane/ethyl acetate 6:1) yielded the title 
compound $15(0.69 \mathrm{~g}, 82 \%)$ as a yellow oil. Spectroscopic data were in agreement with those reported in literature. ${ }^{30}$

(E)-1-(Benzyloxy)-5-[(4"-methoxybenzyl)oxy]-3-methyl-3-penten-2-one (11). To a solution of ylide 13 (2.60 g, $5.95 \mathrm{mmol})$ in $\mathrm{CH}_{2} \mathrm{Cl}_{2}(20 \mathrm{~mL})$ was added aldehyde 14 (1 g, $\left.5.95 \mathrm{mmol}\right)$ and the mixture was stirred at room temperature for $24 \mathrm{~h}$. Concentration in vacuo gave an orange/red oil that was purified by flash chromatography (hexane/ethyl acetate 9:1) to give the title compound $11(1.84 \mathrm{~g}, 91 \%)$ as a light yellow oil for which the spectroscopic data were in agreement with those reported above.

(E)-1-(Benzyloxy)-5-[tert-butyl(diphenyl)silyl]oxy-3-methyl-3-penten-2-one (16). To a solution of ylide $13(2.44 \mathrm{~g}, 5.57 \mathrm{mmol})$ in $\mathrm{CH}_{2} \mathrm{Cl}_{2}(20 \mathrm{~mL})$ was added aldehyde $15(600 \mathrm{mg}$. $2.01 \mathrm{mmol}$ ) and the mixture was heated at reflux for $48 \mathrm{~h}$. Concentration in vacuo gave an orange/red oil that was purified by flash chromatography (hexane/ethyl acetate 9:1) to give the title compound $16(875 \mathrm{mg}, 95 \%)$ as a light yellow oil. $v_{\max }(\mathrm{NaCl}) / \mathrm{cm}^{-1}$ (neat) $3070,3030,2930$, $2857,1690,1671,1472,1428,1112,1055 ; \delta_{\mathrm{H}}\left(300 \mathrm{MHz}, \mathrm{CDCl}_{3}\right) 1.06(9 \mathrm{H}, \mathrm{s}, t-\mathrm{Bu}), 1.57(3 \mathrm{H}, \mathrm{s}$, 3- $\left.\mathrm{CH}_{3}\right), 4.40-4.42\left(2 \mathrm{H}, \mathrm{m}, 5-\mathrm{CH}_{2}\right), 4.41\left(2 \mathrm{H}, \mathrm{s}, 1-\mathrm{CH}_{2}\right), 4.60\left(2 \mathrm{H}, \mathrm{s}, 1\right.$ '- $\left.\mathrm{CH}_{2}\right), 6.59(1 \mathrm{H}, \mathrm{m}, 4-\mathrm{H})$, 7.26-7.43 (11H, m, 2"'-, 4"'-, 6"'-CH and 1"- to 6"-CH), 7.64-7.67 (4H, m, 3"'- and 5"'-CH); $\delta_{\mathrm{C}}$ $\left(75 \mathrm{MHz}, \mathrm{CDCl}_{3}\right) 11.4\left(\mathrm{CH}_{3}, 3-\mathrm{CH}_{3}\right), 26.8\left(\mathrm{CH}_{3}, t-\mathrm{Bu}\right), 61.4\left(\mathrm{CH}_{2}, \mathrm{C}-5\right), 71.7\left(\mathrm{CH}_{2}, \mathrm{C}-1\right), 73.3$ $\left(\mathrm{CH}_{2}, \mathrm{C}-\mathrm{1}^{\prime}\right), 127.9$ (CH, C-2"' and C-6"' ), $127.9(\mathrm{CH}, \mathrm{C}-4 "), 128.0\left(\mathrm{CH}, \mathrm{C}-2^{\prime \prime}\right.$ and C-6"), 128.5 (CH, C-3" and C-5"), 129.9 (CH, C-4"'), 133.1 (quat, C-1"'), 134.1 (quat, C-1"), 135.5 (CH, C-3"' and C-5"'), 137.5 (quat, C-3), 141.9 (CH, C-4), 197.0 (quat, C-2); $m / z$ (EI): 458 (M+1 $0.1 \%$ ), 443 $\left(\mathrm{M}-\mathrm{CH}_{3}, 15\right), 401\left(\mathrm{M}-\mathrm{C}_{4} \mathrm{H}_{9}, 57\right)$ and 91 (100); HRMS (EI): Found $\mathrm{M}^{+}, 458.22650$. $\mathrm{C}_{29} \mathrm{H}_{34} \mathrm{O}_{3} \mathrm{Si}$, requires $\mathrm{M}^{+}, 458.22772$.

Benzyl (E)-5-[tert-butyl(diphenyl)silyl]oxy-3-methyl-2-methylene-3-pentenyl ether (12). A solution of (E)-1-(benzyloxy)-5-[tert-butyl(diphenyl)silyl]oxy-3-methyl-3-penten-2-one 16 (434 $\mathrm{mg}, 0.95 \mathrm{mmol})$ in THF $(5 \mathrm{~mL})$ was cooled to $0^{\circ} \mathrm{C}$. To this solution was added methylenetriphenylphosphorane ylide ${ }^{28}$ in THF $(10 \mathrm{~mL})$. The reaction mixture was stirred at $0{ }^{\circ} \mathrm{C}$ for $1 \mathrm{~h}$, quenched by the addition of sat. aqueous $\mathrm{NaHCO}_{3}(20 \mathrm{~mL})$ and extracted with diethyl ether $(3 \times 20 \mathrm{~mL})$. The combined extracts were dried $\left(\mathrm{MgSO}_{4}\right)$ and concentrated. The residue was purified by flash chromatography (hexane/ether 8:1) to give the title compound 12 (397 mg, 92\%) as a pale yellow oil. $v_{\max }(\mathrm{NaCl}) / \mathrm{cm}^{-1}$ (neat) $3069,2956,2930,2889,2856,1472$, 1454, 1427, 1111, 1055; $\delta_{\mathrm{H}}\left(300 \mathrm{MHz}, \mathrm{CDCl}_{3}\right) 1.05(9 \mathrm{H}, \mathrm{s}, t-\mathrm{Bu}), 1.63\left(3 \mathrm{H}, \mathrm{s}, 3-\mathrm{CH}_{3}\right), 4.19(2 \mathrm{H}$, s, 1- $\left.\mathrm{CH}_{2}\right), 4.38\left(2 \mathrm{H}, \mathrm{d}, J_{5,4} 5.9,5-\mathrm{CH}_{2}\right), 4.53\left(2 \mathrm{H}, \mathrm{s}, 1\right.$ '- $\left.\mathrm{CH}_{2}\right), 5.21\left(1 \mathrm{H}, \mathrm{bs}, 2-\mathrm{CH}_{a} \mathrm{H}_{\mathrm{b}}\right), 5.23(1 \mathrm{H}$, bs, 2- $\left.\mathrm{CH}_{\mathrm{a}} H_{b}\right), 5.85\left(1 \mathrm{H}, \mathrm{t}, J_{4,5} 5.9,4-H\right), 7.26-7.43(11 \mathrm{H}, \mathrm{m}, 2$ "'-, 4"'-, 6"'-CH and 1"- to 6"-CH), 7.64-7.67 (4H, m, 3"'- and 5"'-CH); $\delta_{\mathrm{C}}\left(75 \mathrm{MHz}, \mathrm{CDCl}_{3}\right) 14.3\left(\mathrm{CH}_{3}, 3-\mathrm{CH}_{3}\right), 26.8\left(\mathrm{CH}_{3}, t-\mathrm{Bu}\right)$, $61.6\left(\mathrm{CH}_{2}, \mathrm{C}-5\right), 71.4\left(\mathrm{CH}_{2}, \mathrm{C}-1\right), 72.2\left(\mathrm{CH}_{2}, \mathrm{C}-1^{\prime}\right), 113.5\left(\mathrm{CH}_{2}, 2-\mathrm{CH}_{2}\right), 127.5(\mathrm{CH}, \mathrm{C}-4 "), 127.6$ (CH, C-2'" and C-6"'), 127.7 (CH, C-2" and C-6"), 127.7 (CH, C-4), 128.4 (CH, C-3" and C-5"), 129.6 (CH, C-4"'), 132.9 (quat, C-1"'), 133.8 (quat, C-1"), 135.6 (CH, C-3"' and C-5"'), 138.4 (quat, C-3), 144.0 (quat, C-2); $m / z$ (EI): $456\left(\mathrm{M}^{+}, 0.1 \%\right.$ ), $399\left(\mathrm{M}-\mathrm{C}_{4} \mathrm{H}_{9}, 57\right)$ and 91 (100); HRMS (EI): Found $\mathrm{M}^{+}, 456.24812 . \mathrm{C}_{30} \mathrm{H}_{36} \mathrm{O}_{2} \mathrm{Si}$, requires $\mathrm{M}^{+}, 456.24846$. 
Spiro[bicyclo[2.2.1]hept-5-ene-2,3'-azepan]-1'-carboxylic acid phenylmethyl ester (17). ${ }^{16}$ Copper (II) triflate $(13.8 \mathrm{mg}, 38 \mu \mathrm{mol})$ and 2,2'-isopropylidene-bis[(4S)-4-tert-butyl-2-oxazoline] $(11.2 \mathrm{mg}, 38 \mu \mathrm{mol})$ were combined in a dry box under an inert atmosphere. The sealed flask was then removed from the box and connected to a nitrogen line. Anhydrous $\mathrm{CH}_{2} \mathrm{Cl}_{2}(3 \mathrm{~mL})$ was added, whereupon a green/blue solution formed within $5 \mathrm{~min}$. The solution was stirred for $3 \mathrm{~h}$ at room temperature. At the end of this time the solution was checked visually for the presence of undissolved copper (II) triflate. If present, stirring was continued until all the triflate salt had dissolved, forming a homogeneous green solution of the ligand complex, this was cooled to $78^{\circ} \mathrm{C}$. A solution of lactam $7(50 \mathrm{mg}, 0.19 \mathrm{mmol})$ in $\mathrm{CH}_{2} \mathrm{Cl}_{2}(1 \mathrm{~mL})$ was then added via cannula followed by the addition of freshly distilled cyclopentadiene $(188 \mathrm{mg}, 2.85 \mathrm{mmol})$. The resulting solution was warmed to room temperature and stirred for $3 \mathrm{~h}$. The reaction mixture was then diluted with ethyl acetate/hexane $(1: 1,10 \mathrm{~mL})$, applied directly to a short column of silica gel and eluted with ethyl acetate/hexane $(1: 1)$ to remove the copper salts. Concentration in vacuo afforded the crude product which was purified by flash chromatography (hexane/ethyl acetate 7:1) to give the title compound $17(33 \mathrm{mg}, 53 \%)$ as a yellow oil and as a 2:1 ratio of exo/endo diastereomers. The enantiomeric excess was determined to be $58 \%$ by chiral HPLC by comparison with a racemic sample ${ }^{\mathrm{a}}$ using a Chiralpak AD column [hexane: ${ }^{i} \mathrm{PrOH}=95: 5$, $0.3 \mathrm{~mL} \mathrm{~min}{ }^{-1}, 254 \mathrm{~nm}: t_{\mathrm{r}}($ exo, major enantiomer $)=23.6 \mathrm{~min}, t_{\mathrm{r}}($ exo, minor enantiomer $)=$ $25.5 \mathrm{~min} . t_{\mathrm{r}}($ endo, major enantiomer $)=27.8 \mathrm{~min}, t_{\mathrm{r}}($ endo, minor enantiomer $\left.)=25.0 \mathrm{~min}\right] .[\alpha]_{\mathrm{D}}=$ $+12.25\left(\mathrm{c}=2.4, \mathrm{CHCl}_{3}\right)$. Chemical shifts for the minor conformer due to restricted rotation about the amide bond is indicated by an $\operatorname{asterisk}(*)$.

Major Exo isomer: $v_{\max }(\mathrm{NaCl}) / \mathrm{cm}^{-1}\left(\mathrm{CH}_{2} \mathrm{Cl}_{2}\right) 3054,2986,1764,1707,1332,1162 ; \delta_{\mathrm{H}} \quad(300$ $\left.\mathrm{MHz} ; \mathrm{CDCl}_{3}\right) 1.21(1 \mathrm{H}, \mathrm{bd}, J 11.7,3 \mathrm{~A}-H), 1.46-1.74\left(8 \mathrm{H}, \mathrm{m}, 7-, 4^{\prime}-, 5^{\prime}-\right.$ and 6'-CH $), 2.23(1 \mathrm{H}$, dd, $J_{\text {gem }} 11.7$ and $\left.J_{3,4} 4.0,3 \mathrm{~B}-H\right), 2.84(1 \mathrm{H}, \mathrm{bs}, 4-H), 3.31(1 \mathrm{H}, \mathrm{bs}, 1-H), 3.56-3.66\left(1 \mathrm{H}, \mathrm{m}, 7^{\prime} \mathrm{A}-\right.$ $H), 3.94-4.03\left(1 \mathrm{H}, \mathrm{m}, 7\right.$ 'B-H), $5.24(2 \mathrm{H}, \mathrm{s}, 1$ "-CH $), 6.08\left(1 \mathrm{H}, \mathrm{dd}, J_{6,5} 5.5\right.$ and $\left.\mathrm{J}_{6,4} 3.1,6-H\right), 6.26$ $\left(1 \mathrm{H}, \mathrm{dd}, J_{5,6} 5.5\right.$ and $\left.\mathrm{J}_{5,1} 2.9,5-H\right), 7.29-7.38\left(5 \mathrm{H}, \mathrm{m}, 2\right.$ '"'- to 6"'-CH); $\delta_{\mathrm{C}}\left(75 \mathrm{MHz} ; \mathrm{CDCl}_{3}\right) 26.1$ $\left(\mathrm{CH}_{2}, \mathrm{C}-6^{\prime}\right), 27.1\left(\mathrm{CH}_{2}, \mathrm{C}-5^{\prime}\right), 28.6^{*}\left(\mathrm{CH}_{2}, \mathrm{C}-6^{\prime}\right), 29.1^{*}\left(\mathrm{CH}_{2}, \mathrm{C}-5^{\prime}\right), 35.1\left(\mathrm{CH}_{2}, \mathrm{C}-4{ }^{\prime}\right), 37.6\left(\mathrm{CH}_{2}\right.$, $\left.\mathrm{C}-3), 42.7\left(\mathrm{CH}_{2}, \mathrm{C}-4\right), 44.6\left(\mathrm{CH}_{2}, \mathrm{C}-7\right)^{\prime}\right), 49.1\left(\mathrm{CH}_{2}, \mathrm{C}-7\right), 50.4\left(\mathrm{CH}_{2}, \mathrm{C}-1\right), 57.1$ (quat, $\left.\mathrm{C}-2,3 '\right)$, $68.2\left(\mathrm{CH}_{2}, \mathrm{C}-1^{\prime \prime}\right), 68.5^{*}\left(\mathrm{CH}_{2}, \mathrm{C}-1^{\prime \prime}\right), 127.8\left(\mathrm{CH}, \mathrm{C}-2^{\prime \prime \prime}\right.$ and C-6"'), 127.9* (CH, C-2"' and C-6"'), $128.0\left(\mathrm{CH}, \mathrm{C}-4^{\prime \prime \prime}\right), 128.2^{*}\left(\mathrm{CH}, \mathrm{C}-4^{\prime \prime \prime}\right), 128.5\left(\mathrm{CH}, \mathrm{C}-3^{\prime \prime}\right.$ and $\left.\mathrm{C}-5^{\prime \prime \prime}\right), 128.5^{*}\left(\mathrm{CH}, \mathrm{C}-3^{\prime \prime \prime}\right.$ and C5"'), 133.9 ( $\mathrm{CH}, \mathrm{C}-6), 139.6(\mathrm{CH}, \mathrm{C}-5), 155.3$ (quat, $\mathrm{CO}-\mathrm{CBz}$ ), 175.5* (quat, C-2'), 182.0 (quat, C-2'); Endo Isomer: $\delta_{\mathrm{H}}\left(300 \mathrm{MHz} ; \mathrm{CDCl}_{3}\right) 1.43-1.88\left(10 \mathrm{H}, \mathrm{m}, 3-, 7-, 4^{\prime}-, 5^{\prime}-, 6^{\prime}-\mathrm{CH}_{2}\right), 2.81(1 \mathrm{H}$, bs, 4-H), $3.04(1 \mathrm{H}, \mathrm{bs}, 1-H), 3.43-3.53\left(1 \mathrm{H}, \mathrm{m}, 7^{\prime} \mathrm{A}-H\right), 4.03-4.13\left(1 \mathrm{H}, \mathrm{m}, 7{ }^{\prime} \mathrm{B}-H\right), 5.21(2 \mathrm{H}, \mathrm{s}$, 1 "-C $\left.H_{2}\right), 6.08\left(1 \mathrm{H}, \mathrm{dd}, J_{6,5} 5.8\right.$ and $\left.\mathrm{J}_{6,4} 2.9,6-H\right), 6.13\left(1 \mathrm{H}, \mathrm{dd}, J_{5,6} 5.8\right.$ and $\left.\mathrm{J}_{5,1} 2.9,5-H\right), 7.26-$ $7.39\left(5 \mathrm{H}, \mathrm{m}, 2^{\prime \prime \prime}-\right.$ to $\left.6 " '-\mathrm{CH}\right) ; \mathrm{m} / z(\mathrm{EI}): 325\left(\mathrm{M}^{+}, 1.4 \%\right)$ and 91 (100); HRMS (EI): Found $\mathrm{M}^{+}$, $325.16744 \mathrm{C}_{20} \mathrm{H}_{23} \mathrm{NO}_{3}$, requires $\mathrm{M}^{+}, 325.16779$.

Benzyl (6S)-2,3-Dimethyl-7-oxo-8-azaspiro[5.6]dodec-2-ene-8-carboxylate (18). Procedure using Cu(OTf) 2. Copper (II) triflate $(9.7 \mathrm{mg}, 27 \mu \mathrm{mol})$ and 2,2'-isopropylidene-bis[(4S)-4-tert-

\footnotetext{
${ }^{\text {a }}$ The racemic sample was prepared in the same fashion as above but without the addition of the chiral ligand.
} 
butyl-2-oxazoline] $(7.9 \mathrm{mg}, 27 \mu \mathrm{mol})$ were combined in a dry box under an inert atmosphere. The sealed flask was then removed from the box and connected to a nitrogen line. Anhydrous $\mathrm{CH}_{2} \mathrm{Cl}_{2}(3 \mathrm{~mL})$ was added, whereupon a green/blue solution formed within $5 \mathrm{~min}$. The solution was stirred for $3 \mathrm{~h}$ at ambient temperature. At the end of this time the solution was checked visually for the presence of undissolved copper (II) triflate. If present, stirring was continued until all the triflate salt had dissolved, forming a homogeneous green solution of the ligand complex, which was cooled to $-78{ }^{\circ} \mathrm{C}$. A solution of lactam 7 (37 mg, $\left.0.135 \mathrm{mmol}\right)$ in $\mathrm{CH}_{2} \mathrm{Cl}_{2}$ $(1 \mathrm{~mL})$ was then added via cannula followed by freshly distilled 2,3-dimethyl-1,3-butadiene (166 mg, $2.02 \mathrm{mmol}$ ). The resulting solution was warmed to room temperature and stirred for $3 \mathrm{~h}$. The reaction mixture was then diluted with ethyl acetate/hexane $(1: 1,10 \mathrm{~mL})$, applied directly to a short column of silica gel and eluted with ethyl acetate/hexane (1:1) to remove the copper salts. Concentration in vacuo afforded the crude product which was purified by flash chromatography (hexane/ethyl acetate 8:1) to give the title compound $\mathbf{1 8}(12 \mathrm{mg}, 26 \%)$ as a pale yellow oil. The enantiomeric excess was determined to be $58 \%$ by chiral HPLC by comparison with a racemic sample ${ }^{\mathrm{a}}$ using a Chiralpak AD column [hexane: ${ }^{i}-\mathrm{PrOH}=99: 1,0.3 \mathrm{~mL} \mathrm{~min}^{-1}$, $254 \mathrm{~nm}: t_{\mathrm{r}}($ major enantiomer $)=41.1 \mathrm{~min}, t_{\mathrm{r}}($ minor enantiomer $\left.)=39.4 \mathrm{~min}\right] .[\alpha]_{\mathrm{D}}=+3.0(\mathrm{c}=0.5$, $\left.\mathrm{CHCl}_{3}\right)$.

Procedure using $\mathbf{C u}\left(\mathbf{S b F}_{6}\right)_{2}$. Copper (II) chloride $(6.18 \mathrm{mg}, 46 \mu \mathrm{mol})$ and 2,2'-isopropylidenebis[(4S)-4-tert-butyl-2-oxazoline] $(14.9 \mathrm{mg}, 51 \mu \mathrm{mol})$ and $\mathrm{AgSbF}_{6}(32 \mathrm{mg}, 92 \mu \mathrm{mol})$ were combined in a dry box under an inert atmosphere. The sealed flask was then removed from the box and connected to a nitrogen line. Anhydrous $\mathrm{CH}_{2} \mathrm{Cl}_{2}(2 \mathrm{~mL})$ was added and the flask was wrapped in aluminium foil to protect the reaction mixture from light. The heterogeneous mixture was stirred vigorously for $6 \mathrm{~h}$ at ambient temperature. At the end of this time the mixture was filtered through a short column of Celite and rinsed with $\mathrm{CH}_{2} \mathrm{Cl}_{2}(1 \mathrm{~mL})$ to give a clear, dark blue solution of $[\mathrm{Cu}((S, S)$-tert-Bu-box $)]\left(\mathrm{SbF}_{6}\right)_{2}$ that was cooled to $-78{ }^{\circ} \mathrm{C}$. A solution of lactam 7 (60 mg, $0.23 \mathrm{mmol})$ in $\mathrm{CH}_{2} \mathrm{Cl}_{2}(1 \mathrm{~mL})$ was then added via cannula followed by freshly distilled 2,3-dimethyl-1,3-butadiene $(285 \mathrm{mg}, 3.47 \mathrm{mmol})$. The resulting solution was warmed to room temperature and stirred for $24 \mathrm{~h}$. The reaction mixture was diluted with ethyl acetate/hexane $(1: 1$, $10 \mathrm{~mL}$ ), applied directly to a short column of silica gel and eluted with ethyl acetate/hexane (1:1) to remove the copper salts. Concentration in vacuo afforded the crude product which was purified by flash chromatography (hexane/ethyl acetate 8:1) to give the title compound 18 (23 mg, $30 \%$ ) as a yellow oil. The enantiomeric excess was determined to be $94 \%$ by chiral HPLC by comparison with a racemic sample ${ }^{\mathrm{a}}$ using a Chiralpak AD column [hexane: ${ }^{i}-\mathrm{PrOH}=$ $95: 5,0.3 \mathrm{~mL} \mathrm{~min}^{-1}, 254 \mathrm{~nm}: t_{\mathrm{r}}$ (major enantiomer) $=67.7 \mathrm{~min}, t_{\mathrm{r}}$ (minor enantiomer) $=$ $64.3 \mathrm{~min}] .[\alpha]_{\mathrm{D}}=+12.85\left(\mathrm{c}=2, \mathrm{CHCl}_{3}\right)$.

$v_{\max }(\mathrm{NaCl}) / \mathrm{cm}^{-1}\left(\mathrm{CH}_{2} \mathrm{Cl}_{2}\right) 3054,2986,2930,1752,1702,1380 ; \delta_{\mathrm{H}}\left(400 \mathrm{MHz} ; \mathrm{CDCl}_{3}\right) 1.51(3 \mathrm{H}$, s, 3- $\left.\mathrm{CH}_{3}\right), 1.58\left(3 \mathrm{H}, \mathrm{s}, 2-\mathrm{CH}_{3}\right), 1.61-1.63\left(1 \mathrm{H}, \mathrm{m}, 12-\mathrm{CH}_{2}\right), 1.68-1.71(6 \mathrm{H}, \mathrm{m}, 11-$, 4- and 5$\left.\mathrm{CH}_{2}\right), 1.85(1 \mathrm{H}, \mathrm{bd}, J 16.8,1 \mathrm{~A}-H), 1.91-2.02\left(3 \mathrm{H}, \mathrm{m}, 10-\mathrm{CH}_{2}\right), 2.53(1 \mathrm{H}, \mathrm{bd}, J 16.8,1 \mathrm{~B}-H)$, 3.63-3.70 (1H, m, 9A-H), 3.73-3.81 (1H, m, 9B-H), $5.19(2 \mathrm{H}, \mathrm{s}, 1$ '-CH $), 7.27-7.35(5 \mathrm{H}, \mathrm{m}, 2$ to 6"-CH); $\delta_{\mathrm{C}}\left(100 \mathrm{MHz} ; \mathrm{CDCl}_{3}\right) 18.5\left(\mathrm{CH}_{3}, 3-\mathrm{CH}_{3}\right), 19.3\left(\mathrm{CH}_{3}, 2-\mathrm{CH}_{3}\right), 23.4\left(\mathrm{CH}_{2}, \mathrm{C}-11\right), 26.5$ 
$\left(\mathrm{CH}_{2}, \mathrm{C}-4\right), 28.6\left(\mathrm{CH}_{2}, \mathrm{C}-10\right), 30.5\left(\mathrm{CH}_{2}, \mathrm{C}-5\right), 32.7\left(\mathrm{CH}_{2}, \mathrm{C}-12\right), 40.3\left(\mathrm{CH}_{2}, \mathrm{C}-1\right), 45.1\left(\mathrm{CH}_{2}, \mathrm{C}-\right.$ 9), 48.5 (quat, C-6), $67.8\left(\mathrm{CH}_{2}, \mathrm{C}-1^{\prime}\right), 123.1$ (quat, $\left.\mathrm{C}-2\right), 124.4$ (quat, $\left.\mathrm{C}-3\right), 127.6(\mathrm{CH}, \mathrm{C}-2$ " and C-6"), 128.0 ( $\mathrm{CH}, \mathrm{C}-4 "), 128.5$ ( $\mathrm{CH}, \mathrm{C}-3 "$ and C-5"), 136.1 (quat, C-1"), 154.9 (quat, $\mathrm{CO}-\mathrm{CBz}$ ), 183.1 (quat, C-7); $m / z$ (EI): $341\left(\mathrm{M}^{+}, 3.8 \%\right), 313\left(\mathrm{M}-\mathrm{C}_{2} \mathrm{H}_{4}, 28\right), 250\left(\mathrm{M}-\mathrm{C}_{7} \mathrm{H}_{7}, 91\right), 206$ (135), and 91 (100); HRMS (EI): Found $\mathrm{M}^{+}, 341.19923 \mathrm{C}_{21} \mathrm{H}_{27} \mathrm{NO}_{3}$, requires $\mathrm{M}^{+}, 341.19909$.

\section{References}

1. Seki, T.; Satake, M.; Mackenzie, L.; Kaspar, H. F.; Yasumoto, T. Tetrahedron Lett. 1995, 36, 7093.

2. Garthwaite, I. Trends in Food Science and Technology 2000, 11, 235.

3. Lu, C. K.; Lee, G. H.; Huang, R.; Chou, H. N. Tetrahedron Lett. 2001, 42, 1713.

4. Hu, T. M.; Curtis, J. M.; Oshima, Y.; Quilliam, M. A.; Walter, J. A.; Watson Wright, W. M.; Wright, J. L. C. J. Chem. Soc., Chem. Commun. 1995, 2159.

5. Hu, T. M.; Burton, I. W.; Cembella, A. D.; Curtis, J. M.; Quilliam, M. A.; Walter, J. A.; Wright, J. L. C. J. Nat. Prod. 2001, 64, 308.

6. Cembella, A. D.; Lewis, N. I.; Quilliam, M. A. Nat. Toxins 1999, 7, 197.

7. Uemura, D.; Chou, T.; Haino, T.; Nagatsu, A.; Fukuzawa, S.; Zheng, S. Z.; Chen, H. S. J. Am. Chem. Soc. 1995, 117, 1155.

8. Chou, T.; Kamo, O.; Uemura, D. Tetrahedron Lett. 1996, 37, 4023.

9. Takada, N.; Umemura, N.; Suenaga, K.; Uemura, D. Tetrahedron Lett. 2001, 42, 3495.

10. Hu, T. M.; Curtis, J. M.; Walter, J. A.; Wright, J. L. C. Tetrahedron Lett. 1996, 37, 7671.

11. Stewart, M.; Blunt, J. W.; Munro, M. H. G.; Robinson, W. T.; Hannah, D. J. Tetrahedron Lett. 1997, 38, 4889.

12. Ahn, Y.; Cardenas, G. I.; Yang, J.; Romo, D. Org. Lett. 2001, 3, 751.

13. Furkert, D. P.; Brimble, M. A. Org. Lett. 2002, 4, 3655.

14. Brimble, M. A.; Trzoss, M. Tetrahedron 2004, 60, 5613.

15. Yang, J.; Cohn, S. T.; Romo, D. Org. Lett. 2000, 2, 763.

16. (a) Tsujimoto, T.; Ishihara, J.; Horie, M.; Murai, A. Synlett 2002, 399. (b) Ishihara, J.; Horie, M.; Shimada, Y.; Tojo, S.; Murai, A. Synlett 2002, 403.

17. McCauley, J. A.; Nagasawa, K.; Lander, P. A.; Mischke, S. G.; Semones, M. A.; Kishi, Y. J. Am. Chem. Soc. 1998, 120, 7647.

18. Sakamoto, S.; Sakazaki, H.; Hagiwara, K.; Kamada, K.; Ishii, K.; Noda, T.; Inoue, M.; Hirama, M. Angew. Chem., Int. Ed. in press.

19. White, J. D.; Wang, G; Quaranta, L. Org. Lett. 2003, 5, 4983.

20. Nagasaka, T.; Tamano, H.; Hamaguchi, F. Heterocycles 1986, 24, 1231.

21. Guillena, G.; Mico, I.; Najera, C.; Ezquerra, J.; Pedregal, C. Anales de Quimica Int. Ed. 1996, $92,362$. 
22. (a) Piers, E.; Morton, H. E. J. Org. Chem. 1980, 45, 4264. (b) Piers, E.; Chong, M. J. J. Chem. Soc., Chem. Commun. 1983, 934.

23. For reviews see: (a) Ghosh, A. K.; Mathivanan, P.; Cappiello, J. Tetrahedron Asymmetry, 1998, 9, 1. (b) Johnson, J. S.; Evans, D. A. Acc. Chem. Res. 2000, 33, 325.

24. Evans, D. A.; Murry, J. A.; von Matt, P.; Norcross, R. D.; Miller, S. J. Angew. Chem., Int. Ed. 1995, 34, 798.

25. Berson, J. A.; Hamlet, Z.; Mueller, W. A. J. Am. Chem. Soc. 1962, 84, 297.

26. Roush, W. A.; Brown, B. B. J. Org. Chem. 1992, 57, 3380.

27. Betzer, J. B.; Delaloge, F.; Muller, B.; Pancrazi, A.; J. Prunet, J. J. Org. Chem. 1997, 62, 7768.

28. Roush, W. R.; Russo-Rodriguez, S. J. Org. Chem. 1987, 52, 598.

29. Chenevert, R.; Dasser, M. J. Org. Chem. 2000, 65, 4529.

30. Iannazzo, D.; Piperno, A.; Pistara, V.; Rescifina, A.; Romeo, R. Tetrahedron 2002, 58, 581. 